\title{
East of Shota Rustaveli and Oriental Flavor Russian-language Translations of the Poem
}

\section{Modebadze Irine Igorevna ${ }^{1}$}

Senior Scientific Researcher of Shota Rustaveli Institute of Georgian Literature,Ivane Javakhishvili Tbilisi State University.

(date of receiving: September, 2020; date of acceptance: October, 2020)

\begin{abstract}
"Alienation of the plot", including the transfer to the East, is a fairly common artistic device in the history of world literature. A prerequisite for this is the creation of a special oriental atmosphere of the artistic space of the work. The East of Shota Rustaveli's poem (XII century) covers a huge cultural area and is created with the help of various artistic techniques. To what extent between the artistic reality of the poem and the cultural and historical situation of its epoch preserved when it is transfer in the Russian culture? We have analyzed the markers of Rustaveli's East (intertextual references, cultural concepts, realities) in the main Russian-language translations of the poem. A comparative analysis showed that the Russian-language translations adequately conveyed the "oriental flavor" of the poem, but in the process of domestication the connection with the real East of the Rustaveli era is lost. In our opinion this fact, along with the loss of the philosophical and theological depth and rhythmics of the original, this factor also played a role in the fact that up to the present day the poem is perceived by the Russian-speaking reader more as an "oriental tale", "epic" than the Christian literature work.
\end{abstract}

Keywords: Georgian Literature, Shota Rustaveli, Russian-Language Translations, East Realities, Concepts, Intertextuality.

1. E-mail: irinamodeb@gmail.com 


\title{
Восток Шота Руставели и восточный колорит русскоязычных переводов поэмы
}

\author{
Модебадзе Иринэ Игоревна ${ }^{1}$ \\ Старший научный сотрудник Института грузинской литературы \\ им. Шота Руставели ТСУ им. Ив. Джавахишвили, \\ Тбилиси, Грузия. \\ (дата получения: сентябрь 2020 г.; дата принятия: октябрь 2020 г.)
}

\begin{abstract}
Аннотация
«Отчуждение сюжета», в том числе и перенесение действия на Восток, достаточно распространенный художественный прием в истории мировой литературы. Обязательным условием при этом является создание особой восточной атмосферы художественного пространства произведения. Восток поэмы Шота Руставели (XII в.) охватывает обширный культурный ареал и создается при помощи различных художественных приемов. Насколько сохраняется связь художественной реальности поэмы с культурно-исторической ситуацией эпохи при ее трансляции в поле русской культуры?

Нами были проанализированы маркеры Востока Руставели (интертекстуальные отсылки, культурные концепты, реалии) в основных русскоязычных переводах поэмы. Сопоставительный анализ показал, что в русскоязычных переводах в целом адекватно передан «восточный колорит» поэмы, но в процессе доместикации связь с реальным Востоком эпохи Руставели теряется. Полагаем, что, наряду с утратой философско-богословской глубины и ритмики оригинала, этот фактор также сыграл свою роль: вплоть до сегодняшнего дня поэма воспринимается русскоязычным читателем скорее как восточное сказание, эпос, чем вершинное произведение христианской литературы.
\end{abstract}

Ключевые слова: Грузинская Литература, Шота Руставели, Русскоязычные Переводы, Реалии Востока, Концепты, Интертекстуальность.

1. E-mail: irinamodeb@gmail.com 


\section{Введение}

\section{«Персидское сказание» Шота Руставели}

Поэма Шота Руставели «Вепхисткаосани» (известная русскоязычному читателю как «Витязь в тигровой шкуре») - вершинное произведение грузинской поэзии XII века. Одной из значимых частей ее композиционной структуры является Пролог, которому в эпических произведениях средневековых литератур уделялось особое внимание: в Прологе авторы (Низами Гянджеви, Фирдоуси, Джами, Саади, Кретьен де’Труа, Вольфрам фон Эшенбах и др.) раскрывали читателю замысел своих произведений, обосновывали собственную мировоззренческую позицию и эстетические воззрения. Пролог «Вепхисткаосани» построен в полном соответствии с этой традицией. Тем более интересным представляется тот факт, что в 9 строфе Пролога (нумерацию строф приводим по Руставели 2007), повествуя об истории создания поэмы, автор сообщает, что он «переложил на речь грузинскую <..> персидское сказание». Это утверждение не могло не привлечь внимания комментаторов и исследователей. Еще в начале XVII в. первый издатель поэмы царь Картли Вахтанг VI (1675-1737) в своем «Толковании» («Комментарии») подтвердил, что в персидской литературе не фиксируются следы подобной истории. Выражение «персидское сказание» оказалось поэтическим символом, значимым для интерпретации глубинных смыслов поэмы. Полисемантичность, иносказания, аллюзии и метафоричность органически присущи языку Руставели, и определение смысла b3s๓̋ [спарсули] (дсл. персидский) послужило основанием серьезной научной полемики, в ходе которой было высказано немало различных мнений: «чужой», «нехристианский», «древний» и др. Несмотря на вариативность интерпретаций, не вызывает сомнений тот факт, что, стремясь придать описываемым событиям художественную достоверность, поэт использует определение «персидское» как широкое понятие, охватывающее культурный 
ареал всего Востока, на что указывает и география художественного пространства поэмы.

Как художественный прием «отчуждение сюжета» не такая уж и редкость в истории мировой литературы, в том числе и перенесение действия на Восток (достаточно вспомнить хотя бы «Персидские письма» Шарля Монтескье, «Западно-восточный диван» Гете и др.). Обязательным условием при этом является создание особой, восточной, атмосферы художественного пространства. Достоверность «персидской истории» Руставели создается рядом художественных приемов:

1) действие развивается в условной Аравии - «Арабети» (дсл. краю арабов), в не менее условной Индоети / Индии (стране индов), а также в вымышленных Гуланшаро, Мульгазанзаре и Каджети; упоминаются и вполне реальные Хатаети / Хатай / Китай /, Хваразм / Хорезм /, Балахшан / Бадахшан /, Египет, Багдад и др.;

2) герои поэмы - «мусульмане», более чем условно следующие мусульманским традициям;

3) встречаются апеллирующие к метатексту восточной поэзии интертекстуальные отсылки;

4) упоминаются реалии восточных культур.

Перенесение текста в иноязычную культурную среду - сложный коммуникативный акт: «в отличие от человека говорящего, находящегося внутри “своей” семиосферы, переводчик попадает в пересечение, по крайней мере, двух семиосфер: “своей” и “чужой”, представленной подлежащим переводу текстом» (Базылев, Сорокин 2000. 56) и необходимостью его доместикации (культурной адаптации). Конечно, «все, что сказано или написано одним человеком, должно быть понято другим в процессе восприятия и осмысления» (Семенов 2008. 9), и это бесспорная истина. Но как воспринято и как передано? 
Стремление к наибольшей точности передачи авторского смысла, духа переводимого произведения при условии сохранения ритма и поэтической красоты звучания оригинала неизменно остается основной задачей, стоящей перед любым поэтическим переводом. Сложная система художественноизобразительных средств (метафоры, эпитеты, гиперболизация, аллитерация, эвфонии и т.д.) затрудняет перевод поэмы Руставели на иностранные языки часть многочисленных подтекстов неизбежно утрачивается. При сопоставлении различных переводов поэмы на русский язык нами было отмечено, что «наибольшее количество [расхождений фиксируется] при переводе-интерпретации строк, отражающих религиозно-богословские основы мировоззренческой позиции Руставели. Именно здесь переводчики чаще всего вплотную сталкиваются с основанной на аллегорической функции языка т.н. «проблемой множественности смыслов», когда поэт, «говоря одно, говорит и другое» (Рикер 1995. 97). Чем большее количество смыслов (соответственно, и возможных трактовок) содержит высказывание, тем выше роль субъективного фактора - восприятия текста самим переводчиком, что и позволяет говорить о проблеме перевода в общем контексте проблемы интерпретации (Модебадзе 2008. 423-424). Постепенно «утрачивая связь со своей богословскорелигиозной основой, метафоры и аллегории Руставели обретали статус художественной правды, и за два века интерпретации-рецепции этого памятника сложился ряд устойчивых культурных штампов» (Там же. 428). Все более дистанциируясь от культурного поля своей эпохи, поэма постепенно обретала светско-развлекательный характер, а художественный Восток Руставели, отдаляясь от реального Востока своей эпохи, все более сближался со сказочным миром восточных сказаний.

История переводов поэмы на русский язык началась еще во второй половине XIX века, а последние переводы датируются уже XXI веком. За это время создано более шестидесяти (полных и частичных) русскоязычных 
переводов. Но поскольку нас интересует специфика рецепции поэмы, точнее, вопрос о том, насколько сохраняется дух поэмы при ее трансляции в поле русской культуры, то в качестве материала исследования мы рассмотрим наиболее значимые переводы XX века:

1) близкий к оригиналу прозаический перевод С. Иорданишвили (1937), которым пользовались Н.Заболоцкий, М.Бажан и другие переводчики поэмы;

2) перевод Н.Заболоцкого, наиболее популярный у русскоязычного читателя;

3) перевод Ш.Нуцубидзе - созданный непосредственно с текста оригинала;

4) перевод П.Петренко (при участии К.Чичинадзе).

\section{Основная часть}

І. Интертекстуальные отсылки. Следует особо оговорить, что, рассуждая об условности Востока в художественном пространстве «Вепхисткаосани», было бы огромной ошибкой полагать, что речь идет об условности ориенталисткого типа. Характерной особенностью развития грузинской культуры является тесная связь с восточными культурами: «Наряду с западной, европейской, ориентацией, грузинская культура не порывала связи и с восточными культурами, и это определялось не только географическими, политическими и экономическими факторами, но и тенденциями духовного развития» (Тварадзе 1985. 17). В этом смысле «в грузинской литературе ‘Вепхисткаосани' Шота Руставели - это встреча западной и восточной культур» (Ратиани 2015. 41), что наглядно иллюстрируют фиксируемые в тексте интертекстуальные переклички. Отсылая читателя к вершинным произведения восточной поэзии, они способствуют сопряжению поэмы с метатекстом поэтической культуры Востока. В частности, без каких-либо 
комментариев Руставели упоминает Вис и Рамина Гургани, Ростома / Рустама / Рустема / Фирдоуси, Каэна / Каиса / Кайса / Низами и Саламана Джами - поэт уверен, что читатель прекрасно знает тексты, к которым их отсылает автор. При сравнении с оригиналом несложно заметить, что переводы Стрф. 181.3; Стр.1068.4 и Стрф. 1529.4 (сравнения героев поэмы с Вис и Рамином) адекватны. Аналогично и Стрф.192.3 (упоминание Ростома /Рустама /Ростема). Гораздо менее повезло персонажам Низами и Джами: в Стрф. 1327.4 упоминаются Каэн /Каис/ и Саламан. В переводах читаем:

Иорданишвили: Его терзаний не вынесли бы ни Каис, ни Саламан (Руставели 1966 a)

Н.Заболоцкий: По сравненью с этим горем недостойны описанья/ Саламоновы печали и Каисовы страданья (Руставели 1966 б)

Ш.Нуцубидзе: Этих мук не перенес бы Каис, как и Саламан (Руставели 1979)

П.Петренко: Этих мук не снес бы Каин, Сал исторг бы тяжкий стон (Руставели 1985)

Как видим, в переводах сохранены интертекстуальные отсылки, но в написании имен собственных фиксируются разночтения: Саламан/Саламон/Сал и Каис/Каин. Неудачным представляется перевод П. Петренко, где искажения настолько серьезны, что ведут к полной утрате смысла: Каин ассоциируется с библейской историей братоубийства, поэтому догадаться, кто такой Сал не представляется возможным.

II. Концепты и реалии культур Востока. Не меньшую значимость имеет включение в повествование культурных реалий. Прежде всего, это концепты миджнурство и мусульманство. Обосновывая в Прологе собственное понимание миджнурства, Руставели отсылает читателя к арабской культуре: 
“”Миджнуром” арабь называют неистового» (Стрф. 22.1, пер. С. Иорданишвили). Согласно авторскому замыслу, члены царской династии Арабети, Тинатин и Автандил - арабы, и именно они являют собой истинных миджнуров, превзошедших прославленных Рамина и Вис (см. Стрф. 1529.4). О том, что Автандил араб свидетельствуют его слова: «Я - араб, в Аравии мои палаты» (Стрф. 282.3, пер. С.Иорданишвили) и косвенные детали: в Гуланшаро Фатьме приходится разъяснять Автандилу традиции празднования Навроза, который не признают арабы (Стрф. 1109.1 и 1112.1); обращаясь к светилам, Автандил называет их арабскими именами - Зуал, Myштар, Mapux, Аспироз, Отарид (Стрф. 947-951) и т.д. Мусульманское вероисповедание героев подчеркивается упоминанием различных реалий мусульманской культуры:

1). Неоднократно упоминается дylusogo [мусапи] - Священная книга (Коран). Коран лежит у изголовья Нестан-Дареджан (Стрф. 523.1); на Коране (Книге клятв) клянутся друг другу в верности Тариэл и Нестан-Дареджан (Стрф. 410.1); с Кораном в руках молятся у изголовья впавшего в беспамятство при виде красоты Нестан-Дареджан Тариэла мукры и мулимы. В русскоязычных переводах эта деталь транслируется по-разному. В ряде случаев конкретизируется, о какой именно Священной Книге идет речь, как, скажем в стрф. 523.1 и стрф. 344.2, где все переводчики однозначно указывают - «Коран». В тех случаях, когда переводчики этого не делают, смысл затуманивается, как, напр., в стрф 410.1, где советский читатель вряд ли мог бы с уверенностью утверждать, на какой (и почему?) книгой приносят клятвы герои поэмы:

Над Книгой клятв (Кораном) я клялся и клялась она

(С.Иорданишвили)

Клялся я над книгой клятвы (Н.Заболоцкий) 


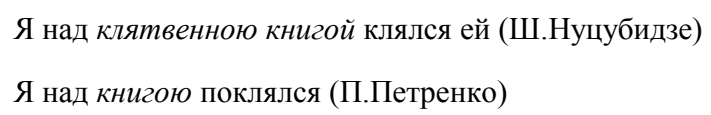

Гораздо больше в этом смысле повезло мукрам, муллимам и хадумам чаще всего они так и упомянуты в переводах, а в словарях к изданиям читатель легко может найти объяснение этих слов. Однако это правило переноса реалий из одного культурного поля в другое соблюдается не всегда: так, например, П.Петренко заменяет муллимов «магами», что у читателя советской эпохи скорее ассоциируется с огнепоклонничеством, чародейством, но никак не с мусульманством.

Упоминание мукров и муллимов однозначно отсылает читателя к контексту мусульманской культуры, однако в Стрф. 342.4 бросается в глаза и определенное несоответствие культурных кодов: «Привели мукров, они назвали мою болезнь колдовством Вельзевула» (С.Иорданишвили). Как видим, в одном предложении имеются маркеры различных культурных ареалов Мусульманского и Христианского миров (мукры и Белзебул/Вельзевул). В поэтических переводах эта деталь передана весьма приблизительно упоминание мукров опущено, что касается Вельзевула, то П.Петренко заменяет имя злого духа на сатана, Н.Заболоцкий, избегая конкретизации, использует понятие «одержимость бесами»:

Стрф. 342.4: Им казалось, что больного бесы мучают незримы (Н.Заболоцкий)

И решили на совете: это сделал Вельзевул (Ш.Нуцубидзе)

Маги званные сказали, что сражен я сатаной (П.Петренко)

2). Особого внимания заслуживает отнотение персонажей поэмы к вину. Коран воспрещает мусульманам пить вино, поэтому к вину, даже молодому (маджари), никогда не прикасались багдадские купщьы (Стрф. 1019.2). В то же 
время «мусульманское» население Индии (Стрф. 476.2) и Арабети (Стрф. 1538.2) не отказывается от вина. Пьют вино и побратимы /герои-витязи/ (Стрф. 1564.4). За исключением некоторых нюансов в русскоязычных переводах этот момент передан адекватно.

3). Герои поэмы - доблестные воины, поэтому особое внимание уделяется их вооружению, подчеркивая высокие боевые качества которого, Руставели подчеркивает, что оно изготовлено прославленными оружейниками Хорезма и Басры (Стрф. 396.4 и Стрф. 1352.2). В поэтических переводах эти реалии в целом переданы адекватно.

Вот уже более семи веков Басра потеряла значимость торгово-культурного центра, но в активном словаре живого грузинского языка слово 8sb๘о [басри] сохранило свое значение как «острый». Так оно и использовано в Стрф. 432.3. Соответственно, перевод ठ̈Ј๘о как острый можно считать адекватным, что и предлагает прозаический перевод С.Иорданишвили (острый меч). Тем не менее, создатели поэтических переводов предпочли, не вдаваясь в историкокультурные и лингвистические тонкости, опустить это слово: меч непобедимый (Н.Заболоцкий); меч (Ш.Нуцубидзе); меч мой (П.Петренко).

4). Упоминание одной из далеких от Грузии азиатских стран и специфика перевода ее названия также представляется значимой деталью. Мы имеем в виду Хатаети. «В поэме Руставели Индия, Арабия, Персия и т.д. осмыслены в соответствии со средневековыми представлениями, что не имеет ничего общего с современной географией» (Церетели 2015. 206). Хатаети - это Хатай. Так называли в эпоху Руставели созданное группой прото-монгольских племен Маньджурии цзи-дань (кидань-монголами, которых обычно называют каракитаями, китаями, или хатаями) на северо-востоке территории современного Китая государство Ляо (VIII-XII вв.). Владения Ляо простирались от озера Балхаш на севере, Алтайских гор на востоке до реки Аму-Дарья на юге. Свою страну жители Ляо называли Кидани, а соседние 
народы - Китайа, Кэтай, Хитай, Хатай, Хитан, Сатай (в английский язык слово вошло как Cathay). Южную территорию Китая, которая в то время управлялась династией Южная Сун, называли Чин, Цинь, Син, Чжина, Манзи, Манци. Впоследствии, объединенная страна, в разных языках получила названия, близкие или к слову Kuтай, или к слову Чин. В оригинале сказано, что Хатаети правит «хан», что также указывает на Китай: титул Небесный Хан был установлен императором Тай-цзуном; после падения империи Ляо правитель Каракитайского /Кара-киданьского/ ханства носил титул гурхан, однако в русских переводах всюду имеем «царь».

Грузия, как один из перевалочных пунктов Великого шелкового пути, была прекрасно осведомлена о жизни азиатских государств. Поэтому и тот факт, что взаимоотношения руставелевских Арабети и Индии с Хатаети довольно-таки нестабильны также мог быть навеян реальностью эпохи: в недалеком будущем Чингиз-хан начнет покорение Китая, Азии, Кавказа и Восточной Европы, но усиление китайско-монгольского влияния, которое в художественном пространстве поэмы олицетворяет Хатаети, беспокоило соседние государства уже в XII веке.

Несмотря на то, что в современном грузинском языке Китай называется Һобэоо [чинети], грузинский читатель, еще в школе изучавший адаптированный текст, знает, что под Хатаети подразумевается Китай (вернее, его северная часть), однако, поскольку в переводах мы имеем xamabbl, xaтайщьы и т.д. и цуаря в качестве их правителя, то, не заглядывая в словари, русскоязычный читатель остается в уверенности, что речь идет о некоей вымышленной стране.

5). В цветописи «Вепхисткаосани» значимое место занимают метафоры, связанные с символикой камней. Чаще всего встречаются упоминания гишера, балахша и лала, значимость и лечебные свойства которых издавна известны на Востоке. 
Черный, непрозрачный с таинственным блеском гишер упомянут в поэме более 30 раз. Это устойчивая метафора ресниц и кос царственных красавиц: царицы Тамар (гишерокосой - Стрф. 3/2), Нестан-Дареджан (сад из роз, из гишеров /щеки и глаза/ - Стрф. 487.3); Тинатин (превратившей гишер в свои ресницы - Стрф. 133.1) и др. Один раз гишер упоминается как метафора щетины, покрывшей лицо Автандила во время долгого странствия: гишеровая поросль (Стрф. 190.4). Художественная функция этого камня в поэме обозначение насыщенного черного цвета с красивым блеском. Гишер (гагат) широко известен на Востоке и в Грузии, где имеется крупное месторождение гишера, но Европе этот камень практически неизвестен. В русских переводах метафора нередко передается как «агат» (камень другого цвета), или опускается. Иногда встречается просто «гишер» без комментария, что затрудняет понимание смысла метафоры.

Балахш /бадахш/ - устойчивая метафора уст царственных красавиц: царицы Тамар (Стрф.5.1-2), Тинатин (Стрф.685.3 и др.), Нестан-Дареждан (Стрф.412.1; Стрф. 1011.2; Стрф.1479.4 и др.). Значительно реже эта метафора используется применительно к мужским персонажам поэмы: Автандилу (Стрф. 71.2; Стрф.1062.3), Автандилу и Придону (Стрф. 999.4), а в переводах метафора либо опускается, либо имеем рубин. Как метафора цвета лица мужских персонажей используется лал (Стрф.: 204.1, 279.4, 373.4, 392.3). И всего один раз, подчеркивая бледность, лал встречается применительно к Нестан-Дареджан. Во всех остальных случаях используется метафора розы. Однако переводы этих метафор, как правило, бессистемны, как, например, перевод Стрф. 999.4:

Хрусталь и рубин были расцвечены то эмалью, то гишером (Иорданишвили)

Хрусталя, бадахи-агата вид (Ш.Нуцубидзе) 
Лал, кристалл, агат и роза - все цвело, все пламенело

(Н.Заболоцкий)

На полях хрустальных сладко лалам сладостным расцвесть

(П.Петренко)

В «Вепхисткаосани» нет ни одного случайного слова: в поэме метафоры камней используются для точного обозначения оттенков красного цвета. Судя по контексту, балахи/бадахи - ярко-алый, а лал - розовый камень. Лал (шпинель, рубицелл) стал известен в европейских странах только после путешествия Марко Поло преимущественно как красный камень из Бадахшана (Бале-рубин, новый камень, похожий на рубин). На арабском и индийском Востоке огненно-красные лалы (месторождение Кух-и-Лал) были известны с незапамятных времен, но их также часто путали с рубинами. По-видимому, в Грузии эпохи Руставели их тоже считали рубинами. Само слово млмео [лали] в современном грузинском языке обозначает рубин. Называя розовую шпинель лал, а ярко-красную - балахш, Руставели четко разграничивает темно-красный драгоценный камень и розовый, менее ценный. Так в Стрф. 387.2 имеем перечисление - «украшенный балахшами и лалами». Однако даже в переводе С.Иорданишвили перечисление отсутствует, но появляется уточнение: «Возвышался балдахин, украшенный рубинами из Бадахшана». Что касается поэтических переводов, то переводчики не делают различия между этими камнями и произвольно переводят их названия:

Трон из злата / Бадахшанскими камнями изукрашенный богато (Н.Заболоцкий)

Ложе, разукрашенное лалом (Ш.Нуцубидзе)

Засверкал престол, большими бадахшанами богат (П.Петренко)

При описании изделий из драгоценных камней в «Вепхисткаосани» упоминается исключительно лал, а не балахш. Это позволяет предположить, 
что в метафорической канве поэмы Руставели учитывал не только различия в цвете, но и различия в ценности камней. В русских переводах оба камня чаще всего переводятся как рубин (стрф.1175.3: «венец из цельного рубина»; стрф. 476.3: «чаши из рубина»- С.Иорданишвили), иногда имеются уточнения типа бадахшанский лал, бадахшанские рубины, но используются они без учета принципов цветописи поэмы Руставели.

В активном словаре русского языка слово лал малоупотребительно, драгоценные камни красного цвета и в наши дни чаще всего называют рубинами. Более того, даже в Словаре к русскоязычному изданию можно прочесть: «Лал (бадахш) - рубин» (Руставели 1979. 238). Исходя из этого, перевод лала и балахша как рубин следует признать адекватным, но замена гишера на агат является ошибкой.

Как видим, в поэтических переводах полностью нарушены принципы метафорической цветописи, не учитываются и маркеры сопряжения художественного пространства поэмы с культурной реальностью эпохи. Даже в тех переводах, где имеется упоминание рубинов из Бадахшана, без специального комментария тесно связанная с культурой Востока символика поэмы полностью теряется.

III. Солнце и Лев: метафора Руставели и мусульманская культура. Эмблема Солнц̧е и Лев (Шир-у-Хуршид / Шир-о-Хоршид) известна всему Востоку, гораздо менее известно о связи этого символа с романтическим преданием о любви султана Гиас-эд-Дин /Кайсдин/ Кей-Хосров II (1236-1245) к своей жене Гюрджи-Хатун. Под этим именем оставила свой след в истории царевна Тамар - внучка прославленной царицы Грузии Тамар-Мепе / Тамары Великой (1166-1209/1213), дочь царицы Грузии Русудан (царствование: 12231245) и Могис-эд-дина / Могисэдина /, сына правителя Арзрума Тохруз-шаха (см. исследования Ак. Гацерелия, Е. Джавелидзе и др.). «Вот что писал по этому поводу <...> грузинский летописец Жамтаагмцерели: “И когда подросла 
их дочь Тамар, узнал султан Рума, сын Нукардина, Гияс ад-Дин о достоинствах царевны. Прислав много даров и подношений, просил он (Русудан) отдать в жены ему дочь ее Тамар и поклялся оставить ее христианкой. Царица Русудан вняла его просьбам. Выдала она дочь свою замуж за Гияс ад-Дина <...> и дала в приданое Ацкуери [крепость Ацкури /sf̆уупю/ - И.M.]"» (Жамтаагмцерели 1959, 212. Перевод цитирую по: Шенгелия 1978. 237-247). Совершенно иначе рассказывает историю этого брака «Сельджук-Наме» /«История сельджуков»/ Ибн-Биби, где брак «наследницы династии Давида [Багратиони - царской династии Грузии - И.M.] и сельджуков» расценивается как политический шаг, предпринятый царицей Русудан с целью обезопасить границы своего государства от сельджукских набегов (см.: Шенгелия 2010. 164-177).

«В истории восточной монеты есть уникальный зооморфный сюжет, который завидно выделяет его из других подобных благодаря ключевой роли и значению, оказанной на символику монгольских выпусков в последующие десятилетия. Такой монетой оказался сюжетный тип «Лев и Солнце» сельджукского султана Кей-Хосрова II» (Исаев 2019). По преданию, став султаном Империи, Кей-Хосров II повелел отчеканить в Силвасе новый дирхем в знак своей любви к супруге (по одной из версий, поводом послужило рождение сына). Произошло это через год после их свадьбы (на монете вычеканена надпись «Великий султан мира и благость веры, Кейхосров Пенукей, по хиджре 638 г.»). На передней части монеты изображен небесный свод и следующие слова: «Имам силою аллаха достигший победы, эмир правоверных». Под сводом располагаются звезды, среди них - солнце, а под солнцем - лев-победитель. Дискос небесного тела украшает женский лик, что явилось большим новшеством для исламской страны того времени и не могло не привлечь внимание исследователей. Ссылаясь на труды известных тюркологов (Ахмета Чайцы/Ahmet Çayc1; 
Оздена Суслу/Süslü, Özden; Догана Кубан /Kuban, Doğan; Генюль Оней/ Öney, Gönül и др.), Толга Эркан (Tolga Erkan) пришёл к выводу, что легенда повествует о реальном факте - женский лик Солнца действительно изображает Гюрджи-Хатун, а Лев - это сам султан: «As the symbol of sun, the face of Georgian Princess Tamar Khatun is depicted inside the disc of the sun. $<\ldots>$ The figure of lion represents Giyaseddin Keyhusrev II" s power and ability/Как символ солнца, на солнечном диске изображено лицо грузинской принцессы Тамар Хатун. <...> Фигура льва представляет силу и способности Гияседдина Кейхусрев II/» (Эркан 2010. 1244-1245).

Известный ещё со времён вавилонской астрономии символ Солнце и Лев имеет устойчивые ближневосточные, а также древнюю грузинскую традиции. «В научной литературе неоднократно отмечалось, что символика Льва должна была проникнуть в Эгейский мир из Азии. <..> Также отмечено, что по всей Азии, особенно в памятниках искусства Ирана и Средней Азии Лев изображается с символом палящего солнца на плече, что должно быть знаком того, что он является его частью» (Сургуладзе 2003. 34).

В отличие от этих традиционных изображений, на силвасском дирхеме солнце находится не за плечами льва, но совмещается с созвездием Льва. В «Вепхисткаосани» широко используется метафора солнияа применительно к женским персонажам - царственным красавицам, и метафора льва применительно к главным мужским персонажам поэмы. Если «символика Льва, спутника Солнца, на которого возложена функция его охраны, понимается как олицетворение мужского начала солярных сил» (см.: Сулава 2009. 136), то встреча Льва и Солнца (Солнце в зодиаке Льва) декодируется как счастливое единение миджнуров. Объединяя Льва-победителя (достигшего высокого положения султана Империи Румийского султана КейХосров) и его солнцеликую красавицу-супругу Гюрджи-Хатун, символика монеты дает возможность интерпретировать ее в общем контексте с 
символикой поэмы Руставели. Более чем вероятно, что сюжет Солнце в созвездии Льва сельджукской монеты, а затем и монгольских монет, был навеян устойчивой метафорой «Вепхисткаосани». Связывая монету с ГюрджиХатун - внучкой той самой царицы Тамар, которой Руставели посвятил свою поэму, предание также свидетельствует в пользу этого предположения. Так образуется обратный вектор - символика христианской поэмы уже в XIII веке становится неотъемлемой частью мусульманской культуры.

\section{Заключение}

Подводя итог, можно утверждать, что в русскоязычных переводах «Вепхисткаосани», несмотря на утрату ряда нюансов, в целом адекватно передан присущий поэме «восточный колорит», однако в процессе доместикации частично, а в ряде случаев полностью теряется связь с реальным Востоком эпохи Руставели. Не исключено, что этот фактор, наряду с другими и, прежде всего, утратой смыслового богатства, философско-богословской глубины оригинала и ритмики (16-сложного шаири), также сыграл свою роль в том, что вплоть до сегодняшнего дня русскоязычным читателем поэма воспринимается скорее как восточное сказание, эпос, чем вершинное произведение христианской литературы.

Художественная симуляция Востока в поэме Руставели настолько достоверна и близка к реальности эпохи, что одна из центральных метафор поэмы, органично вписываясь в традиции восточной ментальности, стала восприниматься как часть мусульманской культуры.

\section{Литература}

1- Базылев В. Н., Сорокин Ю. А. (2000). Интерпретативное переводоведение. Ульяновск: Изд-во «Ульян. ун-та».

2- Жамтаагмцерели (1959). Картлис Цховреба (История Грузии). Т. ІІ. Тбилиси,

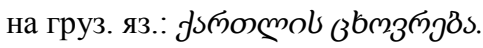


3- Исаев В. Ю. (2019). Дискуссионные вопросы нумизматики. Ж. Нумизматика, Май (№ 45), 2019. URL: https://www.academia.edu/40422458/Isaev_donat_ jochids_rus (Дата обращения: июнь 2020)

4- Модебадзе И. И. (2008). «Вепхисткаосани» - «Витязь в тигровой шкуре» (К вопросу преодоления культурных штампов). Русский язык и культура $в$ зеркале перевода: материаль международной научно-практической конференции. Москва, с. 419-430.

5- Ратиани Ирма (2015). Грузинская литература и мировой литературный прочесс. Тбилиси: Изд-во ТГУ, на грузинском языке: пз8̊osбо, опдs.

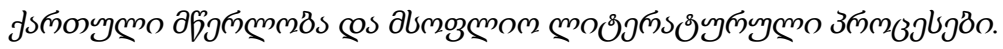

6- Рикер, Поль (1995). Конфликт интерпретащий. Очерки о герменевтике. Москва: Изд-во «Academia-Центр».

7- Руставели, Шота (2007). Витязь в тигровой шкуре, двуязычное издание. СПб.: Изд-во «Вита-Нова».

8- Руставели, Шота (1985). Витязь в тигровой шкуре. Грузинская поэма. Перевод с грузинского Пантелеймона Петренко при участии и под редакцией Константина Чичинадзе. Тбилиси: Изд-во «Мерани».

9- Руставели, Шота (1979). Витязь в тигровой шкуре. Перевод с грузинского Шалвы Нуцубидзе. Тбилиси: Изд-во «Мерани».

10- Руставели, Шота (1966-а). Витязь в тигровой шкуре. Построчный перевод с грузинского С.Иорданишвили. Тбилиси: Изд-во «Литература да хеловнеба».

11- Руставели, Шота (1966-б). Витязь в тигровой шкуре. Перевод с грузинского Н.Заболоцкого. Москва: Изд-во «Художественная литература».

12- Семенов А. Л. (2008). Основы общей теории перевода и переводческой деятельности. Москва: Изд-во «Академия».

13- Сулава, Нестан (2009). «Вепхисткаосани» - метафора, символ, аллюзия,

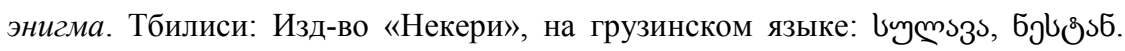

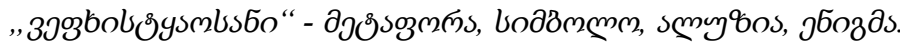

14- Сургуладзе И. (2003). Миф, ритуал, культ в Грузии, Тбилиси: Изд-во «ТГУ»,

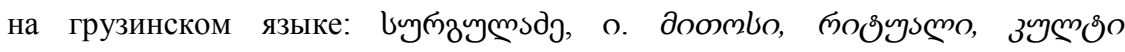

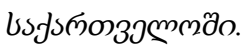

5) Тварадзе Р. (1985). Пятнадизативековое единство. Тбилиси: Изд-во «Сабчота Сакартвело», на грузинском языке: юзЈґ̆дл, ๓.

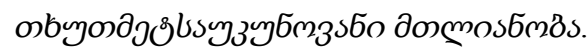


15- Церетели, Лия (2015). Индия «Вепхисткаосани». Руствелология, VI. Тбилиси: Изд-во «ТГУ», стр. 206-224, на грузинском языке: бэґృолмо, моз.

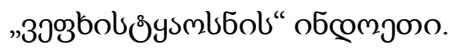

16- Шенгелия Н. Н. (2010). Ибн-Биби о походе на Грузию Ала ад-Дина Кейкобада Османский мир и османистика. Сборник статей $\kappa$ столетию со дня рождения А. С. Тверитиновой (1910-1973). Москва: ИВ PAH, с. 164-177. URL: https://book.ivran.ru/f/osmanskij-mir-i-osmanistika-2010.pdf (Дата обращения: июнь 2020).

17- Шенгелия Н. Н. (1978). Из истории грузино-сельджукских взаимоотношений во второй половине XIII в. Тюркологический сборник, 1978. Москва: Изд-во «Наука», Главная редакция восточной литературы, стр. 237-247.

18- Эркан, Толга (2010). Человеческие фигуры в искусстве Анатолийских сельджуков: сравнение с пещерными рисунками уйгуров и фресками газнавидов в аспекте тематики и морфологии. Erkan, Tolga. Human figures in the Anatolian Seljuk Art: a Comparison to the Cave Drawings of Uygurs and the Murals of Ghaznavids from the Aspects of Theme and Morphology. Turkish Studies, Vol. 5/3 Summer 2010, стр. 1218-1263, на англ.языке. URL: http://www.turkishstudies.net/DergiTamDetay.aspx?ID=1243 doi:10.7827/TurkishStudies.1243. (Дата обращения: июль 2020)

\section{Bibliography}

1- Bazylev V. N., Sorokin Ju. A. (2000). Interpretativnoe perevodovedenie. Ul'janovsk: Izd-vo «Ul'jan. un-ta».

2- Zhamtaagmcereli (1959). Kartlis Chovreba (Istorija Gruzii). T. II. Tbilisi, na gruz.

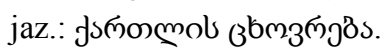

3- Isaev V. Ju. (2019). Diskussionnye voprosy numizmatiki. Zh. Numizmatika, Maj (№ 45), 2019. URL: https://www.academia.edu/40422458/Isaev_donat_jochids_rus (Data obrashhenija: ijun' 2020)

4- Modebadze I. I. (2008). «Vephistkaosani» - «Vitjaz' v tigrovoj shkure» (K voprosu preodolenija kul'turnyh shtampov). Russkij jazyk $i$ kul'tura $v$ zerkale perevoda: materialy mezhdunarodnoj nauchno-prakticheskoj konferencii. Moskva, s. 419-430.

5- Ratiani Irma (2015). Gruzinskaja literatura i mirovoj literaturnyj process. Tbilisi:

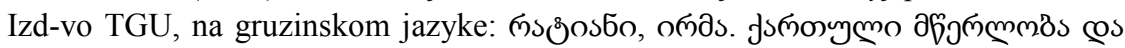

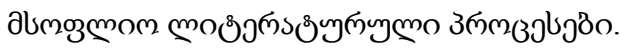

6- Riker, Pol' (1995). Konflikt interpretacij. Ocherki o germenevtike. Moskva: Izd-vo «Academia-Centr». 
7- Rustaveli, Shota (2007). Vitjaz'v tigrovoj shkure, dvujazychnoe izdanie. -SPb.: Izdvo «Vita-Nova».

8- Rustaveli, Shota (1985). Vitjaz'v tigrovoj shkure. Gruzinskaja pojema. Perevod s gruzinskogo Pantelejmona Petrenko pri uchastii i pod redakciej Konstantina Chichinadze. Tbilisi: Izd-vo «Merani».

9- Rustaveli, Shota (1979). Vitjaz'v tigrovoj shkure. Perevod s gruzinskogo Shalvy Nucubidze. Tbilisi: Izd-vo «Merani».

10- Rustaveli, Shota (1966-a). Vitjaz' v tigrovoj shkure. Postrochnyj perevod s gruzinskogo S.Iordanishvili. Tbilisi: Izd-vo «Literatura da helovneba».

11- Rustaveli, Shota (1966-b). Vitjaz' v tigrovoj shkure. Perevod s gruzinskogo N.Zabolockogo. Moskva: Izd-vo «Hudozhestvennaja literatura».

12- Semenov A. L. (2008). Osnovy obshhej teorii perevoda i perevodcheskoj dejatel'nosti. Moskva: Izd-vo «Akademija».

13- Sulava, Nestan (2009). «Vephistkaosani» - metafora, simvol, alljuzija, jenigma. Tbilisi: Izd-vo «Nekeri», na gruzinskom jazyke: bymşs, 5 joss 5.

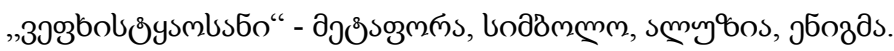

14- Surguladze I. (2003). Mif, ritual, kul't v Gruzii, Tbilisi: Izd-vo «TGU», na

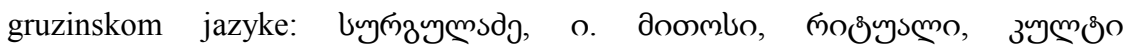

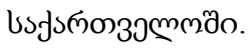

15- Tvaradze R. (1985). Pjatnadcativekovoe edinstvo. Tbilisi: Izd-vo «Sabchota

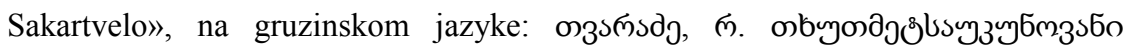
домомб5m8s.

16- Cereteli, Lija (2015). Indija «Vephistkaosani». Rustvelologija, VI. Tbilisi: Izd-vo «TGU», str. 206-224, na gruzinskom jazyke: бэґ̆лолмо, mos.

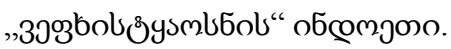

17- Shengelija N. N. (2010). Ibn-Bibi o pohode na Gruziju Ala ad-Dina Kejkobada Osmanskij mir i osmanistika. Sbornik statej $k$ stoletiju so dnja rozhdenija A. S. Tveritinovoj (1910-1973). Moskva: IV RAN, s. 164-177. URL: https://book.ivran.ru/f/osmanskij-mir-i-osmanistika-2010.pdf (Data obrashhenija: ijun' 2020).

18- Shengelija N. N. (1978). Iz istorii gruzino-sel'dzhukskih vzaimootnoshenij vo vtoroj polovine XIII v. Tjurkologicheskij sbornik, 1978. Moskva: Izd-vo «Nauka», Glavnaja redakcija vostochnoj literatury, str. 237-247. 
19- Jerkan, Tolga (2010). Chelovecheskie figury v iskusstve Anatolijskih sel'dzhukov: sravnenie s peshhernymi risunkami ujgurov i freskami gaznavidov $\mathrm{v}$ aspekte tematiki i morfologii. Erkan, Tolga. Human figures in the Anatolian Seljuk Art: a Comparison to the Cave Drawings of Uygurs and the Murals of Ghaznavids from the Aspects of Theme and Morphology. Turkish Studies, Vol. 5/3 Summer 2010, str. 1218-1263, na angl.jazyke. URL: http:/www.turkishstudies.net/DergiTamDetay. aspx?ID=1243 doi:10.7827/TurkishStudies.1243. (Data obrashhenija: ijul' 2020).

\section{HOW TO CITE THIS ARTICLE}

Модебадзе, И. (2021). East of Shota Rustaveli and Oriental Flavor Russian-language Translations of the Poem. Issledovatel'skiy Zhurnal Russkogo Yazyka I Literatury, 9(1). 67-88.

DOI: $10.52547 /$ iarll.17.67

URL: https://www.journaliarll.ir/index.php/iarll/article/view/145

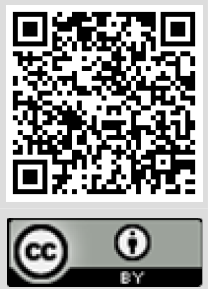




\title{
شرق شاتا روستاولى و اصالت شرقى ترجمههاى روسى منظومه
}

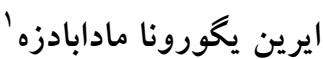

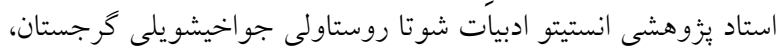

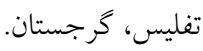

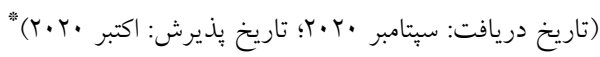

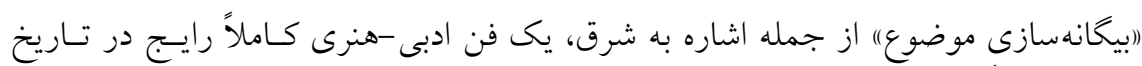

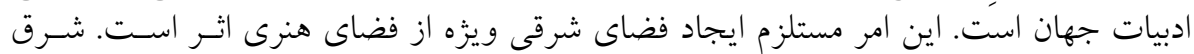

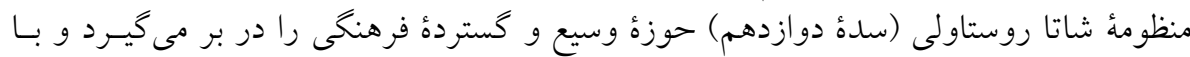

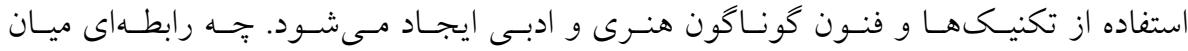

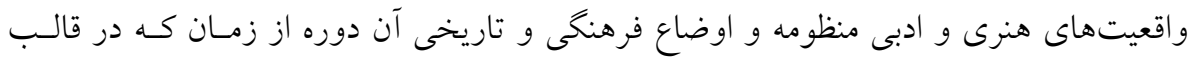

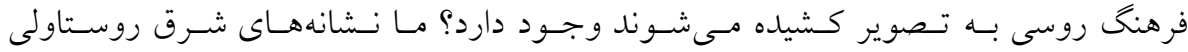

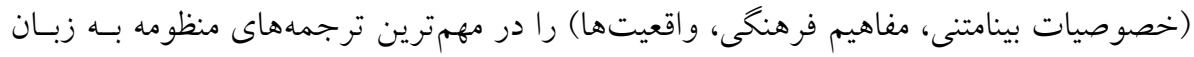

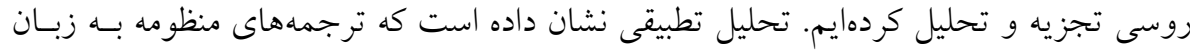

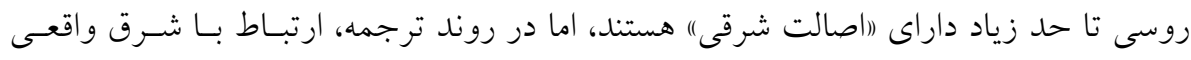

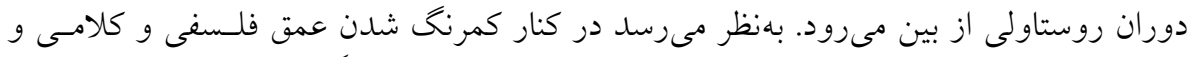

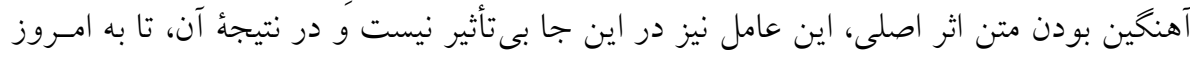

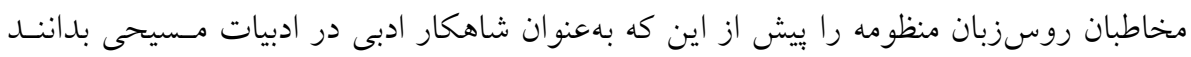

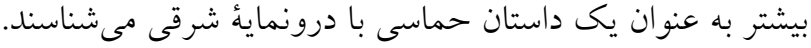

وازگكان كليدى: ادبيات گرجى، شاتا روستاولى، ترجمههاى روسىى، واقعيـت شـرقى، مفـاهيم، 